\title{
Cotton Tolerance to Hoplolaimus columbus and Impact on Population Densities
}

\author{
S. R. Koenning, Department of Plant Pathology, College of Agriculture and Life Sciences, North Carolina State \\ University, Raleigh 27695-7616; and D. T. Bowman, Department of Crop Science, College of Agriculture and Life \\ Sciences, North Carolina State University, Raleigh 27695-7620
}

\begin{abstract}
Koenning, S. R., and Bowman, D. T. 2005. Cotton tolerance to Hoplolaimus columbus and impact on population densities. Plant Dis. 89:649-653.

Glyphosate-tolerant transgenic-cotton cultivars were evaluated for tolerance to Hoplolaimus columbus in field experiments conducted from 2001 to 2003. The studies were arranged in a split-plot design that included treatment with 1,3-dichloropropene at 42 liter/ha to establish fumigated versus nonfumigated subplots with cultivars as whole plots. Cotton cultivars were divided by relative maturity into two separate but adjacent experiments in order to facilitate cotton defoliation, with 10 early-maturity and 5 late-maturity cultivars. Fumigation was effective in suppressing $H$. columbus population densities and increased cotton lint yield. The cultivarfumigation interaction was significant for early-season cotton cultivars but not for late-season cultivars. A tolerance index ([yield of nontreated/yield of treated] $\times 100$ ) was used to compare cultivar differences. Both groups of cultivars expressed significant levels of tolerance to $\mathrm{H}$. columbus, but late-season cultivars tended to yield more than early-season cultivars in infested fields.
\end{abstract}

Additional keywords: Columbia lance nematode, fumigant nematicide

The Columbia lance nematode Hoplolaimus columbus Sher is limited in known distribution to Georgia, North Carolina, South Carolina, and Alabama in the United States (17). This nematode can be a destructive pathogen of cotton (Gossypium hirsutum L.), corn (Zea mays L.), and soybean (Glycine max L.), especially in sandy soils $(15-21,25)$.

Tactics for management of $H$. columbus are limited. Rotation often is not an option in fields infested with this nematode due to its wide host range (10). Peanut (Arachis hypogaea L.) and tobacco (Nicotiana tabacum L.) can be used in rotation with host crops, but the hectarage of and demand for these two crops are limited. Various cultural practices, including small grain cover crops, planting date, stalk destruction, and relative maturity date, have little impact on population densities of $H$. columbus or cotton yield $(8,16)$. Subsoiling in soils with a hardpan increases cotton

Corresponding author: S. R. Koenning E-mail: stephen_koenning@ ncsu.edu

The research reported in this publication was funded, in part, by the North Carolina Agricultural Research Service. The use of trade names does not imply an endorsement by the North Carolina Agricultural Research Service of the products named nor criticisms of similar ones not mentioned. Additional support was provided by Cotton Incorporated Project Number 01-968NC.

Accepted for publication 17 February 2005.

DOI: 10.1094/PD-89-0649

(C) 2005 The American Phytopathological Society yield when $H$. columbus is present, but many farmers have adopted reduced tillage practices $(12,25)$. The application of poultry litter is effective in suppressing midseason population densities of Columbia lance nematode and improving cotton lint yield, but rates required for nematode suppression may exceed environmental guidelines (15).

Fumigant and nonfumigant nematicides are effective in preventing soybean and cotton yield suppression by this nematode, and cotton production in nematodeinfested fields is highly dependent on nematicides. Additional alternative tactics for nematode management in cotton are needed $(3,13,17-19,25,26)$.

Cotton cultivars vary in their response to parasitism by nematodes. Cultivars resistant to the southern root-knot nematode Meloidogyne incognita generally are defined as limiting the reproduction of this species, whereas susceptible cultivars support large numbers of this parasite $(9,24)$. Little variation in reproduction of $\mathrm{H}$. $\mathrm{co}$ lumbus has been noted among soybean and cotton cultivars, which may indicate that there is no specific host-plant resistance to this nematode in these plant species $(6,13,21)$. Cultivars that support nematode reproduction but suffer less yield suppression compared with other cultivars are referred to as being tolerant $(2,7,24)$. Soybean tolerance to a number of nematodes, including $H$. glycines and $H$. columbus, is well documented $(5,13,14,21,22,24)$. Cotton tolerance to $H$. columbus, however, is not well documented and much of the research on this subject is contradictory
$(6,16,18)$. Information on cultivar resistance to root-knot nematodes may be obtained through greenhouse experiments, but tolerance must be evaluated in field experimentation $(6,9,11,13,14,26)$.

The widespread use of herbicidetolerant or insect-resistant cotton cultivars has resulted in numerous cultivars being obsolete. Currently, over $90 \%$ of the cotton hectarage in North Carolina is planted to transgenic cultivars tolerant to the herbicide glyphosate (1). Data on field tolerance and resistance of transgenic cultivars to pests and pathogens is generally lacking. Field research conducted from 2001 through 2003 evaluated the relative tolerance to $H$. columbus of glyphosate-tolerant cotton cultivars with or without transgenic insect resistance. The objectives of this research were to evaluate the impact of this nematode species on cotton lint yield of most herbicide-tolerant cotton cultivars being evaluated in the North Carolina official cultivar trials during these years, the reproductive capacity of $H$. columbus on these cultivars, and to determine whether measurable tolerance to this nematode species is available in commonly used cotton cultivars.

\section{MATERIALS AND METHODS}

Field experiments were conducted over the years 2001 to 2003 in growers fields infested with $H$. columbus. The cotton cultivars to be evaluated were divided by relative maturity into two separate but adjacent experiments. The experiments in 2001 and 2002 were located in different areas of the same field in Scotland County, NC. The soil type at this location was a Wagram loamy sand ( $84 \%$ sand, $11 \%$ silt, $5 \%$ clay, $<1 \%$ organic matter). The mean initial population density (Pi) per $500 \mathrm{~cm}^{3}$ of soil in 2001 was $412 \pm 21$ and $515 \pm 31$ for early- and late-maturing cultivars, respectively, and the mean Pi for 2002 was $278 \pm 25$ and $302 \pm 11$ for early- and latematuring cultivars, respectively. Experiments in 2003 were located in Robeson County, NC in a grower's field with a Goldsboro sandy loam ( $82 \%$ sand, $14 \%$ silt, $4 \%$ clay; $<1 \%$ organic matter) and mean Pi of $332 \pm 18$ and $234 \pm 20 \mathrm{H}$. columbus per $500 \mathrm{~cm}^{3}$ of soil for early- and late-maturing cultivars, respectively.

The experimental design was a split-plot with six replicates. Subplots were treated with 1,3-dichloropropene (Telone II; Dow AgroSciences, Indianapolis, IN) at 42 liter/ha versus nontreated. Whole plots 
were planted to transgenic glyphosatetolerant cotton cultivars with or without transgenic insect resistance (Table 1). Standard management practices for cotton production were used throughout this research and plots were not irrigated (1).

Selected plots were fumigated in early April and all plots planted in mid-May. All plots received an in-furrow application of aldicarb (Temik 15G; Bayer Crop Science Inc., Research Triangle Park, NC) at $0.5 \mathrm{~kg}$ a.i./ha at planting for early-season insect control. Plots were two rows, $12.2 \mathrm{~m}$ long with $1.01-\mathrm{m}$ row spacing and $3.6-\mathrm{m}$ alleys. Cotton was defoliated the last week in September and harvested approximately 2 weeks later. Lint yield was determined by ginning subsamples of seed cotton taken from the first two replicates after picking with a commercial cotton picker.

Samples for nematode assays for each plot were collected prior to fumigation

Table 1. Cotton lint yield as influenced by cultivar and application of 1,3-dichloropropene (1,3-D) at 42 1/ha and tolerance index for 10 early to midseason cotton cultivars and for five mid- to late-maturity cotton cultivars in experiments in fields infested with Hoplolaimus columbus conducted from 2001 to 2003 in Scotland and Robeson Counties, $\mathrm{NC}^{\mathrm{w}}$

\begin{tabular}{lccc}
\hline & \multicolumn{2}{c}{ Lint yield (kg/ha) $^{\mathbf{x}}$} & \\
\cline { 2 - 3 } Cultivar $^{\mathbf{y}}$ & Fumigated 1,3-D & Nontreated & TI \\
\hline Early-season cultivars & & & \\
DP 425RR & $698 \mathrm{ed}$ & $722 \mathrm{bcd}$ & $106 \mathrm{a}$ \\
DP 436RR & $753 \mathrm{ed}$ & $752 \mathrm{bc}$ & $101 \mathrm{ab}$ \\
DP 422B/RR & $671 \mathrm{e}$ & $532 \mathrm{e}$ & $83 \mathrm{~d}$ \\
ST 4892BR & $878 \mathrm{ab}$ & $792 \mathrm{a}$ & $92 \mathrm{abcd}$ \\
ST 4793R & $727 \mathrm{ed}$ & $688 \mathrm{~cd}$ & $93 \mathrm{abcd}$ \\
SG 215BG/RR & $844 \mathrm{bc}$ & $761 \mathrm{~b}$ & $92 \mathrm{abcd}$ \\
SG 501BR & $907 \mathrm{a}$ & $747 \mathrm{bc}$ & $82 \mathrm{~d}$ \\
SG 521R & $740 \mathrm{ed}$ & $749 \mathrm{bc}$ & $100 \mathrm{abc}$ \\
PM 1218BG/RR & $705 \mathrm{ed}$ & $671 \mathrm{~d}$ & $100 \mathrm{abc}$ \\
PM 1199 RR & $778 \mathrm{~cd}$ & $672 \mathrm{~d}$ & $88 \mathrm{bcd}$ \\
Mean & $770 \mathrm{~A}$ & $709 \mathrm{~B}$ & $\ldots$ \\
Late-season cultivars & & & \\
DP451B/RR & $963 \mathrm{a}$ & $932 \mathrm{a}$ & $95 \mathrm{ab}$ \\
DP458BRR & $882 \mathrm{ab}$ & $792 \mathrm{~b}$ & $88 \mathrm{ab}$ \\
DP655BRR & $902 \mathrm{ab}$ & $856 \mathrm{~b}$ & $101 \mathrm{a}$ \\
DP5415RR & $902 \mathrm{ab}$ & $781 \mathrm{~b}$ & $91 \mathrm{ab}$ \\
DP5690RR & $838 \mathrm{~b}$ & $678 \mathrm{c}$ & $80 \mathrm{~b}$ \\
Mean & $898 \mathrm{~A}$ & $806 \mathrm{~B}$ & $\ldots$ \\
\hline
\end{tabular}

${ }^{\mathrm{w}}$ Tolerance indices $(\mathrm{TI})$ were calculated where TI $=$ (yield of nontreated/yield of treated $) \times 100$.

${ }^{x}$ Means followed by the same lowercase letter in a column do not differ according to Waller Duncan $\mathrm{k}$ ratio $t$ test $(k$-ratio $=50)$. The cultivar-fumigation interaction was significant for cotton lint yield for early-season cultivars $(P=0.02)$, but not for late-season cultivars $(P \leq 0.10)$. Mean for each cultivar is based on 18 observations, six replicates per year.

y Cultivar designation containing " $\mathrm{B}$ " indicates transgenic insect resistance.

${ }^{\mathrm{z}}$ Means for relative maturity (fumigated with 1,3-D versus nontreated) followed by the same uppercase letter do not differ according to analysis of variance $(P \leq 0.05)$.

Table 2. Partial analysis of variance and analysis of covariance for main effects and first-order interactions using $\log (\mathrm{Pi}+1)$ as a covariate for midseason $(\mathrm{Pm})$ and harvest $(\mathrm{Pf})$ population density of Hoplolaimus columbus per $500 \mathrm{~cm}^{3}$ of soil, and cotton lint yield for 15 cotton cultivars in a split-plot design and tolerance index analyzed as a randomized complete block design

\begin{tabular}{lccccc}
\hline & & \multicolumn{4}{c}{$\boldsymbol{F}$ value $^{\mathbf{x}}$} \\
\cline { 3 - 6 } Source, maturity & df & Pm & Pf $^{\mathbf{y}}$ & Yield & TI $^{\mathbf{z}}$ \\
\hline Early-season cultivars & & & & & \\
$\quad$ Year & 2 & $203^{* *}$ & $478^{* *}$ & $1,120^{* *}$ & $5.43^{* *}$ \\
Cultivar & 9 & 1.21 & 1.36 & $7.75^{* *}$ & $2.06^{*}$ \\
Fumigant & 1 & $56.7^{* *}$ & $43.9^{* *}$ & $20.70^{* *}$ & $\ldots$ \\
Cultivar-fumigant & 9 & 0.71 & 0.41 & $2.31^{*}$ & $\ldots$ \\
Year-cultivar & 18 & 1.55 & 1.00 & $4.55^{* *}$ & 1.01 \\
Fumigant-year & 2 & $30.40^{* *}$ & $29.2^{* *}$ & $3.75^{*}$ & $\ldots$ \\
Log (Pi + 1) & 1 & $12.40^{* *}$ & $10.34^{* *}$ & $8.55^{* *}$ & $13.63^{* *}$ \\
Late-season cultivars & & & & & \\
Year & 2 & $99.10^{* *}$ & $38.48^{* *}$ & $535^{* *}$ & $6.29^{* *}$ \\
Cultivar & 4 & 1.11 & 0.61 & $5.58^{* *}$ & 1.43 \\
Fumigant & 1 & $41.60^{* *}$ & $6.51^{*}$ & $23.1^{* *}$ & $\ldots$ \\
Cultivar-fumigant & 4 & 0.28 & 0.89 & 1.44 & $\ldots$ \\
Year-cultivar & 8 & 0.45 & 0.95 & $14.98^{* *}$ & 0.96 \\
Fumigant-year & 2 & $8.62^{* *}$ & $7.01^{* *}$ & 0.87 & $\ldots$ \\
Pi & 1 & 1.59 & 0.16 & $3.63^{*}$ & 1.42 \\
\hline
\end{tabular}

${ }^{x}$ Values followed by $*$ and $* *$ are significant at $P \leq 0.10$ and 0.01 , respectively.

${ }^{\mathrm{y}}$ Analysis performed on transformed values $(\log X+1)$.

${ }^{\mathrm{z}}$ Tolerance indices $(\mathrm{TI})$ were calculated where $\mathrm{TI}=($ yield of nontreated/yield of treated $) \times 100$.
(Pi), mid-season $(\mathrm{Pm})$, and at cotton harvest $(\mathrm{Pf})$. Each soil sample consisted of 8 to 10 cores $(2.5 \mathrm{~cm}$ in diameter) taken to a depth of $15 \mathrm{~cm}$ and composited. A $500-\mathrm{cm}^{3}$ subsample was processed by elutriation and centrifugation to extract adult and juvenile nematodes from soil (4).

Analysis of variance (ANOVA) was used for a split-plot design with $\log (\mathrm{Pi}+1)$ as a covariate using PC/SAS software (SAS Institute, Cary, NC). Early- and latematuring cultivars were analyzed separately. Nematode numbers were transformed $\log (x+1)$ prior to analysis to standardize the variance. Nontransformed numbers are presented in tables for clarity. Years for the field experiments were considered to be random effects; therefore, the cultivar-year interaction was used to test differences for cultivar, fumigation, and cultivar-fumigation effects for combined analysis over years. Years differed $(P \leq$ $0.01)$, and first-order interactions for year and cultivar were not observed $(P \leq 0.10)$ for population data, but were observed for yield data. Second-order interactions were not significant.

Tolerance indices (TI) were calculated where $\mathrm{TI}=$ (yield of nontreated/yield of treated) $\times 100$ and analyzed as a randomized complete block design (RCBD). The Waller Duncan $k$-ratio $t$ test $(k$-ratio $=50)$ was used for mean separation and regression analysis was used to evaluate the influence of $\mathrm{Pi}$ and the tolerance index on $\mathrm{Pf}$ and $\mathrm{Pm}$ on data from nontreated plots as an RCBD. Data on nematodes from nontreated plots were subjected to regression analysis and used to determine whether a relationship between nematode reproduction and cotton lint yield was present. Comparison of transgenic insectresistant cultivars with susceptible cultivars was by orthogonal contrasts.

\section{RESULTS}

Fumigation with 1,3-dichloropropene was effective in suppressing the population density of $H$. columbus $(P \leq 0.01)$ at midseason all years (Tables 1 and 2; Fig. 1). Nematode numbers were suppressed $(P \leq$ 0.10 ) by fumigation at cotton harvest in 2001 and 2002, but not in 2003 as indicated by the year-fumigation interaction $(P \leq 0.10)$. Early-season cotton cultivars had lower $(P=0.0026)$ nematode numbers in fumigated plots at midseason in all years and lower $(P \leq 0.10)$ Pf numbers in fumigated plots in 2001 and 2002, but not in 2003 (Fig. 1A). Late cotton cultivars had lower $(P=0.0015)$ nematode numbers in fumigated plots at midseason in all years and lower $(P \leq 0.10)$ Pf nematode levels in fumigated plots in 2001 and 2002, but not in 2003 (Fig. 1B). Cotton cultivars did not differ $(P \leq 0.10)$ in their ability to support reproduction of $H$. columbus, and there was no year-cultivar interaction $(P \leq$ $0.10)$ for either early-season or late-season cultivars. Covariate analysis demonstrated 
that Pi was an important factor influencing nematode Pm and Pf for early cotton cultivars, but not for late cotton cultivars. Analysis of nematode population data from nonfumigated plots showed that Pm was positively related to preplant population density (Fig. 2). There was no apparent difference associated with insect resistance according to orthogonal comparison of means of insect-resistant cultivars versus cultivars without the $\mathrm{Bt}$ resistance transgene (data not included). Similarly, there was no relationship between insect resistance and the tolerance index, in that both groups contained $H$. columbustolerant and -sensitive cultivars.

Fumigation increased $(P \leq 0.01)$ the yield of both early-season and late-season cotton compared with nonfumigated plots (Tables 1 and 2). The first-order cultivarfumigation interaction was significant $(P=$ $0.041)$ for early cultivars, but not $(P=$ 0.17 ) for late-maturing cultivars in the combined analysis over all years (Table 2). Analysis of covariance provides some evidence that $\mathrm{Pi}$ was a more important factor for yield of early compared with late cotton cultivars because $\mathrm{Pi}$ was a significant covariate $(P=0.0003)$ for nonfumigated early cultivars, whereas $P i$ was not a significant covariate $(P=0.24)$ for the late cultivars. Although a valid statistical comparison of early- versus late-maturing cultivars cannot be performed, late-maturing cultivars yielded considerably more than early cultivars.

Mean tolerance indices for early-season cultivars ranged from 82 to 106 for earlyseason cultivars, and from 80 to 101 for late cultivars demonstrating considerable variation in cultivar tolerance (Table 1). Year had an impact $(P \leq 0.01)$ on cultivar tolerance for both groups, but the yearcultivar interaction was not significant $(P \leq$ 0.10 ), showing a high level of consistency in tolerance rankings over years. Tolerance index was not correlated with yield for either late or early cultivars $(P \leq 0.10)$. Nonetheless, the highest-yielding early cultivars in fumigated plots tended to be the least tolerant; whereas, among the late cultivars, the highest-yielding cultivars in fumigated plots were those most tolerant to Columbia lance nematode. Midseason numbers of $H$. columbus were negatively related $(P \leq$ 0.0026 ) to the tolerance index, but final nematode densities were not (Fig. 3).

\section{DISCUSSION}

In 2 of the 3 years of this study, fumigation with 1,3-dichloropropene suppressed $H$. columbus numbers at cotton harvest compared with nonfumigated plots. Because of its relatively low rate of reproduction on cotton compared with other plantparasitic nematodes such as root-knot and reniform nematodes, $H$. columbus cannot compensate for the initial kill by relatively high rates of 1,3-dichloropropene. The positive relationship between preplant nematode population density and Pm confirms the relatively low reproductive rate for this nematode, but also may be related to between-plot variation in soil texture or other edaphic factors that favor reproduction and are reflected in variation in $\mathrm{Pi}$ between plots. The use of analysis of covariance with $\mathrm{Pi}$ as a covariate serves the same purpose, but the use of a quantifiable edaphic factor as a covariate might provide greater insight into the biology and ecology of this nematode. These data also suggest that techniques used in precision agriculture may be useful for management of Columbia lance nematode. The primary constraint on site-specific management of plant-parasitic nematodes is the need for large numbers of nematode assays to accurately quantify potential yield loss (17). Soil texture and other edaphic factors are relatively easy to measure and not subject to temporal variation as are nematode population densities, and a single measure may be sufficient for years. Thus, a map of field soil characteristics could be substituted for nematode density and management tactics applied accordingly.

Population densities of $H$. columbus at midseason and cotton harvest were not influenced by cultivar according to ANOVA, as has been reported in other research $(16,18)$. The negative relationship between $H$. columbus midseason density and TI, however, may indicate a small difference in reproduction of this nematode related to cultivar. Root-knot-resistant cotton cultivars generally were more tolerant than susceptible cultivars in other research, but tolerant cultivars may actually support greater levels of nematode reproduction $(7,9)$. Soybean cultivars tolerant to Heterodera glycines supported more reproduction by this nematode and, in theory, tolerant cultivars may support more nematode reproduction $(7,14)$.

The consistent positive yield response of some cultivars to fumigation and minimal response of other cultivars across years in the presence of Hoplolaimus columbus demonstrates the existence of useable tolerance to $H$. columbus in certain cotton cultivars. Earlier research on this nematode species on cotton indicated that tolerance may exist, but conclusive evidence for tolerance, such as a cultivar-fumigant, interaction was lacking (16). Three cultivars with tolerance indices less than 85 (SG 501BR, DP 422B/RR, and DP $5690 R R$ ) all had yield losses of more than $100 \mathrm{~kg} / \mathrm{ha}$, whereas there was little or no loss in yield of cultivars with a TI greater than 90. Both the early and late cotton maturity groups contained cultivars that displayed distinct and repeatable levels of
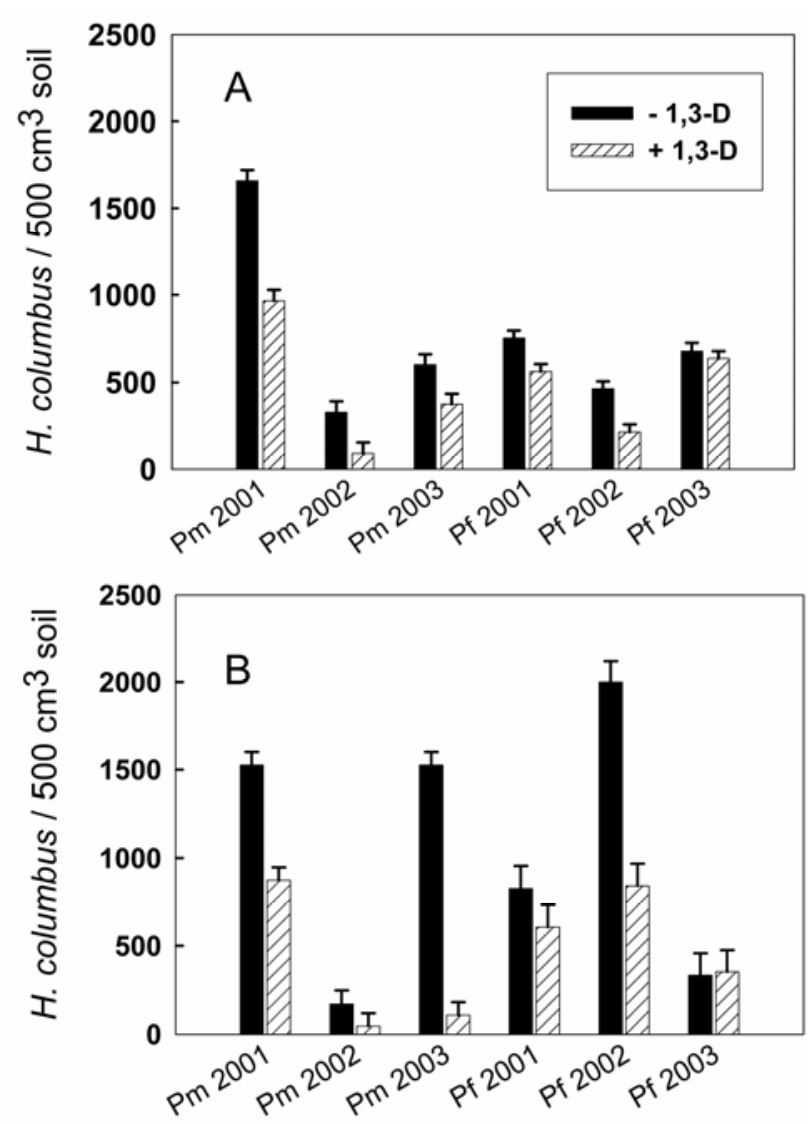

Fig. 1. Influence of in-furrow injection of 1,3-dichloropropene (1,3-D) on midseason (Pm) and final (Pf) population densities of Hoplolaimus columbus per $500 \mathrm{~cm}^{3}$ of soil in field plots from 2001 to 2003. Means are least squared means and error bars are the standard error. A, Early-season and B, mid- to late-season cotton cultivars. 
tolerance $(\mathrm{TI} \geq 95: \mathrm{DP} 451 \mathrm{~B} / \mathrm{RR}$, DP 655BRR, DP 425RR, DP 436RR, SG 521BG/RR, and PM1218 BG/RR), but late-season cultivars generally yielded more than early-season cultivars in fields infested with $H$. columbus. Also, lateseason cultivars were less sensitive to $H$. columbus $\mathrm{Pi}$ than early-season cultivars as evidenced by covariate analysis. The trend for higher yield in infested fields and
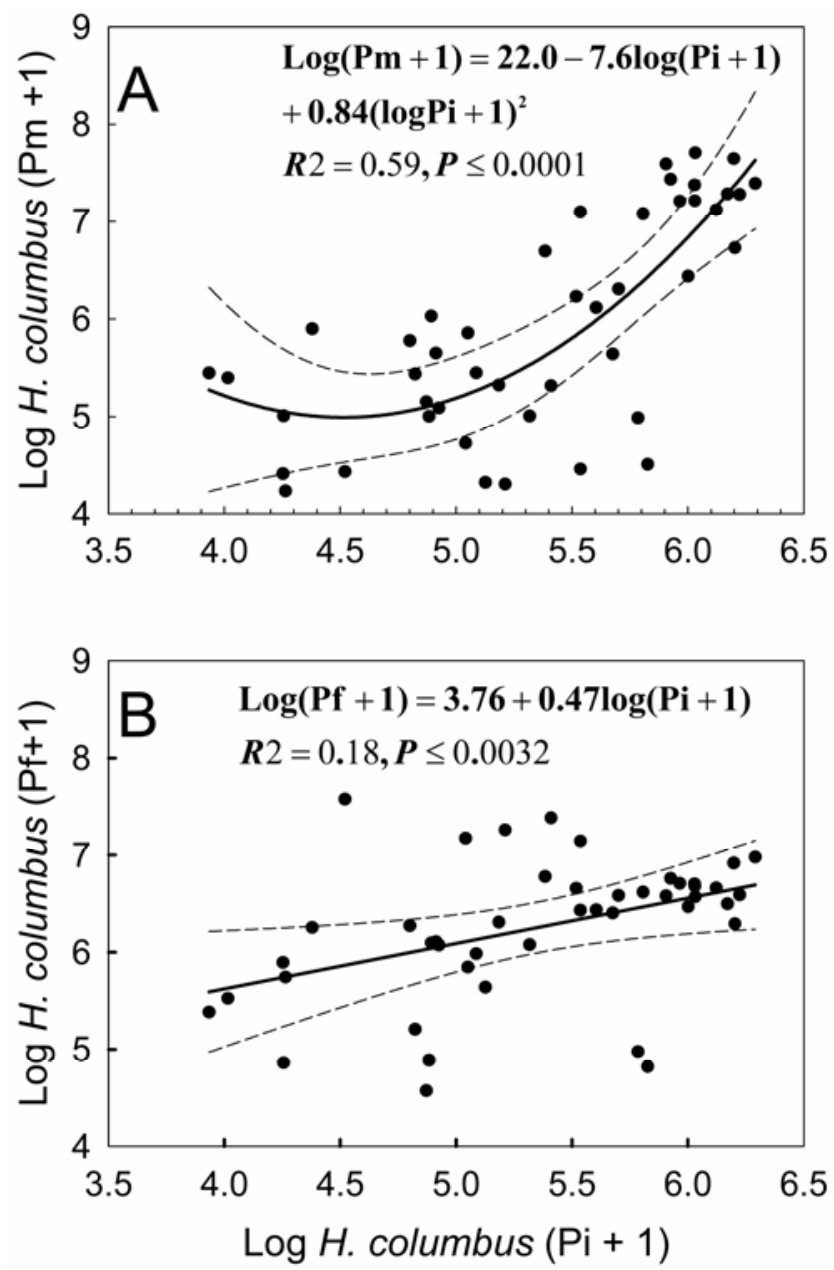

Fig. 2. Impact of preplant $(\log [\mathrm{Pi}+1])$ Hoplolaimus columbus population density per $500 \mathrm{~cm}^{3}$ of soil on A, midseason (Pm) and B, harvest (Pf) H. columbus numbers. Dashed lines are $99 \%$ confidence limits.

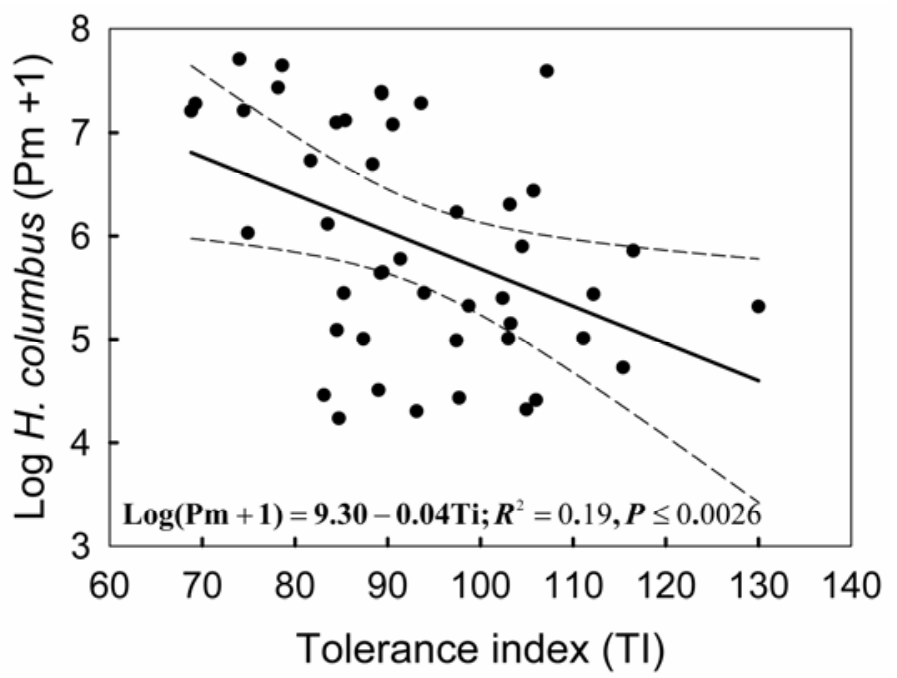

Fig. 3. Relationship between tolerance index (TI) and midseason (Pm) population densities of Hoplolaimus columbus per $500 \mathrm{~cm}^{3}$ of soil. Dashed lines are $99 \%$ confidence limits.

greater tolerance to Columbia lance nematode of late-maturing cultivars compared with early cultivars may not be related to tolerance, but to the following: (i) latematuring cultivars are less determinant than early cultivars and (ii) the less determinate growth habit gives these cultivars a better ability to recover from drought or other stress which is common in the sandy fields where this nematode occurs. Unfortunately, the mechanisms by which tolerance acts are poorly understood, although they may be related to rooting pattern or root growth dynamics, as is the case with soybean cyst nematode (22). Potentially, late-maturing cotton cultivars may prove to be more tolerant to nematode parasites than early cultivars because of their less determinant growth pattern.

The use of cultivars tolerant to $\mathrm{H}$. columbus is a viable option for growers when this nematode is present at damaging levels. Tolerance to nematodes, however, is density dependent, and additional tactics may be required to manage $H$. columbus if population densities greatly exceed the damage threshold $(5,7,14)$. Still, a grower should be able to use less nematicide or a nonfumigant nematicide rather than a fumigant nematicide with a tolerant cotton cultivar to optimize economic return. Tolerance, however, is not the only criterion for cultivar selection, because yield potential may be of more importance. With latematuring cultivars, cultivar selection is straightforward because the two highestyielding cultivars in fumigated or nonfumigated plots were DP $451 \mathrm{~B} / \mathrm{RR}$ and DP 655BRR, which also had the highest tolerance indices (TI $=95$ and 101, respectively). The situation is problematic with the early-maturing cultivars because the highest-yielding early maturity cultivar in nonfumigated plots was SG 501BR, which was also the least tolerant $(\mathrm{TI}=82)$, and the four most tolerant cultivars ( $\mathrm{TI} \geq 100$ ) had an average yield of $723 \mathrm{~kg} / \mathrm{ha}$ in nonfumigated plots compared with $747 \mathrm{~kg} / \mathrm{ha}$ for SG 501BR. The optimal compromise for a cotton grower would be selection of the early cultivar ST 4892BR (TI of 92) because it was the highest-yielding cultivar in nontreated plots $(792 \mathrm{~kg} / \mathrm{ha})$ and did not differ significantly from SG 501BR in treated plots. The data indicate that breeding goals should include selection for both high yield and tolerance.

Research comparing cultivar response to $H$. columbus at varying population densities is needed but difficult to achieve in practice. Evaluation of tolerance at different population levels requires extensive land and material for testing (14,23). Comparison of fumigated versus nonfumigated plots appears to be the most costeffective means for evaluating tolerance $(6,13,14,23)$. Expanded screening of soybean, cotton, and corn germ plasm may identify resistance or greater levels of tolerance to this nematode. The impact of 
cropping systems, cover crops, and potential changes in cultural practices on $H$. columbus also require investigation.

\section{ACKNOWLEDGMENTS}

We thank cooperative extension agent D. E. Morrison; agricultural research technicians R. N. Taylor, J. Ward, J. Denton, and D. Parrish; and research assistant S. M. Morrison for excellent assistance with all aspects of this research.

\section{LITERATURE CITED}

1. Anonymous. 2004. Cotton Information. North Carolina Cooperative Extension Service, College of Agriculture and Life Sciences, AG 417, North Carolina State University, Raleigh.

2. Barker, K. R. 1993. Resistance/tolerance and related concepts/terminology in plant nematology. Plant Dis. 77:111-113.

3. Barker, K. R., and Koenning, S. R. 1998. Developing sustainable systems for nematode management. Annu. Rev. Phytopathol. 36:165205.

4. Barker, K. R., Townshend, J. F., Bird, G. W., Thomason, I. J., and Dickson, D. W. 1986. Determining nematode population responses to control agents. Pages 283-296 in: Methods for Evaluating Pesticides for Control of Plant Pathogens. K. D. Hickey, ed. American Phytopathological Society Press, St. Paul, MN.

5. Boerma, H. R., and Hussey, R. S. 1984. Tolerance to Heterodera glycines in soybean. J. Nematol. 16:289-296.

6. Bowman, D. T., and Schmitt, D. P. 1994. Screening cotton for tolerance to Hoplolaimus columbus. Plant Dis. 78:695-697.

7. Cook, R., and Evans, K. 1987. Resistance and tolerance. Pages 179-231 in: Principles and
Practice of Nematode Control in Crops. R. H. Brown and B.R. Kerry, eds. Academic Press, London.

8. Davis, R. F., Baird, R. E., and McNeill, R. D. 2000. Efficacy of cotton root destruction and winter cover crops for suppression of Hoplolaimus columbus. Suppl. J. Nematol. 32:550555.

9. Davis, R. R., and May, O. L. 2003. Relationships between tolerance and resistance to Meloidogyne incognita in cotton. J. Nematol. 35:411-416.

10. Fassuliotis, G. 1974. Host range of the Columbia lance nematode Hoplolaimus columbus. Plant Dis. Rep. 58:1000-1002.

11. Hill, A. S., May, O. L, and Mueller, J. D. 1994. Evaluation of tolerance to Meloidogyne incognita and Hoplolaimus columbus in cotton genotypes. (Abstr.) J. Nematol. 6:550.

12. Hussey, R. S. 1977. Effect of subsoiling and nematicides on Hoplolaimus columbus populations and cotton yield. J. Nematol. 9:83-86.

13. Koenning, S. R. 2002. Tolerance to Hoplolaimus columbus in glyphosate-resistant transgenic soybean cultivars. J. Nematol. 34:370-373.

14. Koenning, S. R., Anand, S. C., and Meyers, G. O. 1992. An alternative method for evaluating tolerance to Heterodera glycines in field plots. J. Nematol. 24:177-182.

15. Koenning, S. R., Edmisten, K. L., Barker, K. R., Bowman, D. T., and D. E. Morrison. 2003. Effects of rate and time of application of poultry litter on Hoplolaimus columbus. Plant Dis. 87:1244-1249.

16. Koenning, S. R., Edmisten, K. L., Barker, K. R., and Morrison, D. E. 2003. Impact of cotton production systems on management of Hoplolaimus columbus. J. Nematol. 35:73-77.
17. Koenning, S. R., Kirkpatrick, T. L., Starr, J. L. Walker, N. A., Wrather, J. A., and Mueller, J. D. 2004. Plant-parasitic nematodes attacking cotton in the U. S.: old and emerging problems. Plant Dis. 88:100-113.

18. Mueller, J. D., and Sullivan, M. J. 1988. Response of cotton to infection by Hoplolaimus columbus. Ann. Appl. Nematol. (J. Nematol. 20 Suppl.) 2:86-89.

19. Noe, J. P. 1990. Efficacy of fumigant nematicides to control Hoplolaimus columbus on cotton. Suppl. J. Nematol 22:718-723.

20. Noe, J. P. 1993. Damage functions and population changes of Hoplolaimus columbus on cotton and soybean. J. Nematol 25:440-445.

21. Nyczepir, A. P., and Lewis, S. A. 1979. Relative tolerance of selected soybean cultivars to Hoplolaimus columbus and possible effects of soil temperature. J. Nematol. 11:27-31.

22. Radcliffe, D. E., Hussey, R. S., and McClendon, R. W. 1990. Cyst nematode vs. tolerant and intolerant soybean cultivars. Agric. J. 82:855-860.

23. Reese, P. F., Boerma, H. R., and Hussey, R. S. 1988. Resource allocation in experiments measuring soybean tolerance to soybean cyst nematode. Crop Sci. 28:589-593.

24. Roberts, P. A. 2002. Concepts and consequences of resistance. Pages 23-41 in: Plant Resistance to Parasitic Nematodes. J. L. Starr R. Cook, and J. Bridge, eds. CABI Publishing, New York.

25. Schmitt, D. P., and Bailey, J. E. 1990. Chemi cal control of Hoplolaimus columbus on cotton and soybean. Suppl. J. Nematol. 22:689-694.

26. Schmitt, D. P., and Imbriani, J. L. 1987. Management of Hoplolaimus columbus with tolerant soybean and nematicides. Ann. Appl Nematol (J. Nematol. 19 Suppl.) 1:59-63. 